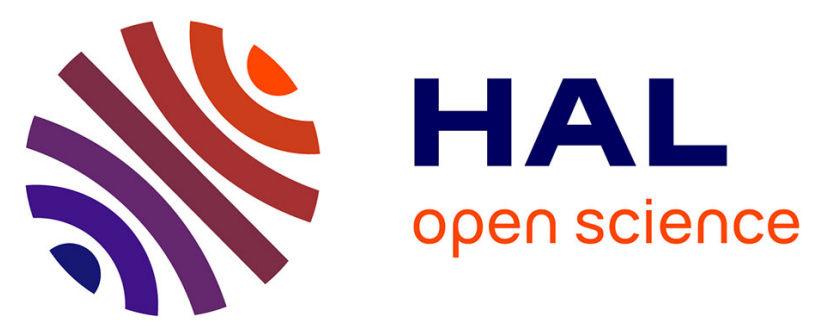

\title{
SFE/SFEDP adrenal insufficiency French consensus: Introduction and handbook
}

Yves Reznik, Pascal Barat, Jérôme Bertherat, Claire Bouvattier, Frederic

Castinetti, Olivier Chabre, Philippe Chanson, Christine Cortet, Brigitte

Delemer, Bernard Goichot, et al.

\section{To cite this version:}

Yves Reznik, Pascal Barat, Jérôme Bertherat, Claire Bouvattier, Frederic Castinetti, et al.. SFE/SFEDP adrenal insufficiency French consensus: Introduction and handbook. Annales d'Endocrinologie, 2018, 79 (1), pp.1 - 22. 10.1016/j.ando.2017.12.001 . hal-01724190

\section{HAL Id: hal-01724190 \\ https://hal-amu.archives-ouvertes.fr/hal-01724190}

Submitted on 10 Apr 2018

HAL is a multi-disciplinary open access archive for the deposit and dissemination of scientific research documents, whether they are published or not. The documents may come from teaching and research institutions in France or abroad, or from public or private research centers.
L'archive ouverte pluridisciplinaire HAL, est destinée au dépôt et à la diffusion de documents scientifiques de niveau recherche, publiés ou non, émanant des établissements d'enseignement et de recherche français ou étrangers, des laboratoires publics ou privés. 


\title{
SFE/SFEDP adrenal insufficiency French consensus: Introduction and handbook
}

\author{
Consensus sur l'insuffisance surrénale de la SFE/SFEDP : introduction et guide
}

\author{
Yves Reznik $^{\mathrm{s}, \mathrm{t}, *}$, Pascal Barat ${ }^{\mathrm{a}}$, Jérôme Bertherat ${ }^{\mathrm{b}}$, Claire Bouvattier ${ }^{\mathrm{c}}$, Frédéric Castinetti $^{\mathrm{d}}$, Olivier \\ Chabre $^{\mathrm{e}}$, Philippe Chanson ${ }^{\mathrm{f}, \mathrm{g}}$, Christine Cortet $^{\mathrm{h}}$, Brigitte Delemer ${ }^{\mathrm{i}}$, Bernard Goichot ${ }^{\mathrm{j}}$, Damien \\ Gruson $^{\mathrm{k}}$, Laurence Guignat ${ }^{\mathrm{b}}$, Emmanuelle Proust-Lemoine ${ }^{\mathrm{l}}$, Marie-Laure Raffin Sanson ${ }^{\mathrm{m}, \mathrm{n}}$, Rachel \\ Reynaud $^{\mathrm{o}}$, Dinane Samara Boustani ${ }^{\mathrm{p}}$, Dominique Simon ${ }^{\mathrm{q}}$, Antoine Tabarin ${ }^{\mathrm{r}}$, Delphine Zenaty ${ }^{\mathrm{q}}$ \\ a Service d'endocrinologie et diabétologie pédiatriques, hôpital des Enfants, CHU de Bordeaux, place Amélie-Raba-Léon, Bordeaux cedex, France \\ ${ }^{\mathrm{b}}$ Service des maladies endocriniennes et métaboliques, hôpital Cochin, CHU Paris Centre, 75014 Paris, France \\ ' Service d'endocrinologie de l'enfant, hôpital de Bicêtre, GHU Paris Sud, Le Kremlin-Bicêtre, France \\ ${ }^{\mathrm{d}}$ UMR7286, CNRS, CRN2M, service d'endocrinologie, hôpital La-Conception, Aix Marseille université, AP-HM, Marseille, France \\ e Service d'endocrinologie diabétologie nutrition, CHU Grenoble-Alpes, 38043 Grenoble cedex, France

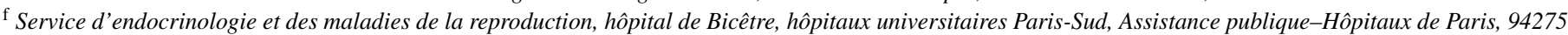 \\ Le Kremlin Bicêtre, France \\ g Inserm 1185, faculté de médecine Paris Sud, université Paris-Sud, université Paris-Saclay, 94276 Le Kremlin-Bicêtre, France \\ ${ }^{\mathrm{h}}$ Service d'endocrinologie, diabétologie et maladies métaboliques, CHRU de Lille, rue Polonowski, Lille cedex, France \\ i Service d'endocrinologie - maladies métaboliques, hôpital Robert-Debré, CHU de Reims, avenue du Général-Koenig, 51092 Reims cedex, France \\ j Service de médecine interne, endocrinologie et nutrition, hôpitaux universitaires de Strasbourg, 67098 Strasbourg cedex, France \\ ${ }^{\mathrm{k}}$ Pôle de recherche en endocrinologie, diabète et nutrition, department of laboratory medicine, institut de recherche expérimentale et clinique, cliniques \\ universitaires Saint-Luc, université catholique de Louvain, Brussels, Belgium \\ ${ }^{1}$ Polyclinique d'Aguilera, 21, rue de l'Estagnas, 64200 Biarritz, France \\ $\mathrm{m}$ Service d'endocrinologie et nutrition, hôpital Ambroise-Paré, AP-HP, Boulogne-Billancourt, France \\ ${ }^{\mathrm{n}}$ Inserm U1173, université Versailles-Saint-Quentin, Montigny-Le-Bretonneux, France \\ ${ }^{\circ}$ Service de pédiatrie multidisciplinaire, CHU Timone-Enfants, AP-HM, 13005 Marseille, France \\ p Service d'endocrinologie, gynécologie et diabétologie pédiatrique, hôpital Necker, CHU de Paris, Paris, France \\ q Service d'endocrinologie diabétologie pédiatrique, hôpital Robert-Debré, centre de référence des maladies endocriniennes rares de la croissance et du \\ développement, université Paris Diderot, Assistance publique-Hôpitaux de Paris, 48, boulevard Sérurier, 75019 Paris, France \\ ${ }^{\mathrm{r}}$ Service d'endocrinologie, diabète et nutrition, université de Bordeaux, CHU de Bordeaux, 33604 Pessac, France \\ ${ }^{s}$ Service d'endocrinologie diabète et maladies métaboliques, CHU de Caen, 14033 Caen cedex, France \\ ${ }^{\mathrm{t}}$ Université de Caen, 14032 Caen cedex, France
}

\begin{abstract}
The French endocrinology society (SFE) and the French pediatric endocrinology society (DFSDP) have drawn up recommendations for the management of primary and secondary adrenal insufficiency in the adult and child, based on an analysis of the literature by 19 experts in 6 workgroups. A diagnosis of adrenal insufficiency should be suspected in the presence of a number of non-specific symptoms except hyperpigmentation which is observed in primary adrenal insufficiency. Diagnosis rely on plasma cortisol and ACTH measurement at 8am and/or the cortisol increase after synacthen administration. When there is a persistant doubt of secondary adrenal insufficiency, insulin hypoglycemia test should be carried out in adults, adolescents and children older than 2 years. For determining the cause of primary adrenal insufficiency, measurement of anti-21hydroxylase antibodies is the initial testing. An adrenal CT scan should be performed if auto-antibody tests are negative, then assay for very long
\end{abstract}

\footnotetext{
* Corresponding author.

E-mail address: reznik-y@ chu-caen.fr (Y. Reznik).
} 
chain fatty acids is recommended in young males. In children, a genetic anomaly is generally found, most often congenital adrenal hyperplasia. In the case of isolated corticotropin (ACTH) insufficiency, it is recommended to first eliminate corticosteroid-induced adrenal insufficiency, then perform an hypothalamic-pituitary MRI. Acute adrenal insufficiency is a serious condition, a gastrointestinal infection being the most frequently reported initiating factor. After blood sampling for cortisol and ACTH assay, treatment should be commenced by parenteral hydrocortisone hemisuccinate together with the correction of hypoglycemia and hypovolemia. Prevention of acute adrenal crisis requires an education of the patient and/or parent in the case of pediatric patients and the development of educational programs. Treatment of adrenal insufficiency is based on the use of hydrocortisone given at the lowest possible dose, administered several times per day. Mineralocorticoid replacement is often necessary for primary adrenal insufficiency but not for corticotroph deficiency. Androgen replacement by DHEA may be offered in certain conditions. Monitoring is based on the detection of signs of under- and over-dosage and on the diagnosis of associated auto-immune disorders.

(C) 2017 Elsevier Masson SAS. All rights reserved.

Keywords: Consensus; Adrenal insufficiency; Primary and secondary; Adults and children

\section{Résumé}

La Société française d'endocrinologie (SFE) et la Société française d'endocrinologie pédiatrique (SFEDP) ont élaboré des recommandations sur la prise en charge de l'insuffisance surrénale primaire et secondaire de l'adulte et de l'enfant, à partir d'une analyse de la littérature réalisée par 19 experts répartis en 6 groupes de travail. Le diagnostic d'insuffisance surrénale doit être évoqué devant l'association de signes cliniques et biologiques non spécifiques, en dehors de la mélanodermie observée dans l'insuffisance surrénale primaire. Le diagnostic repose sur les dosages du cortisol et de l'ACTH le matin et/ou le dosage du cortisol après stimulation par l'ACTH synthétique (synacthène). En cas de doute, le test d'hypoglycémie insulinique est le test de référence chez l'adulte l'adolescent et l'enfant de plus de 2 ans. La recherche étiologique est basée sur le dosage en $1^{\text {re }}$ intention des anticorps anti 21-hydroxylase. En cas de négativité, un scanner surrénalien sera réalisé, puis le dosage des acides gras à chaînes longues sera effectué chez le garçon. Chez l'enfant, une cause génétique sera recherchée, principalement l'hyperplasie congénitale des surrénales. Devant un déficit corticotrope, après la recherche d'une prise prolongée de glucocorticoïdes sera effectuée une imagerie hypothalamo-hypophysaire. L'insuffisance surrénale aiguë est une complication grave souvent déclenchée par une infection gastro-intestinale. Elle nécessite après prélèvement pour dosage du cortisol et ACTH l'administration parentérale d'hémisuccinate d'hydrocortisone et la correction de l'hypovolémie et/ou de l'hypoglycémie. Sa prévention repose sur l'éducation thérapeutique du patient pour laquelle des programmes seront développés. Le traitement de l'insuffisance surrénale s'appuie sur la prise pluriquotidienne d'hydrocortisone à la dose la plus faible possible. La substitution minéralocorticoïde est réalisée en cas d'insuffisance surrénale primaire mais n'est pas nécessaire en cas d'insuffisance surrénale secondaire. La substitution androgénique par la DHEA peut être proposée dans certaines indications précises. La monitoring comportera la recherche de signes cliniques et biologiques de sous/surdosage et de maladies auto-immunes associées.

Mots clés : Consensus ; Insuffisance surrénale ; Primaire et secondaire ; Adultes et enfants

\section{Introduction}

The French endocrinology society (SFE) and the French pediatric endocrinology society (DFSDP) have drawn up recommendations for the management of primary and secondary adrenal insufficiency in the adult and child, based on an analysis of the literature by 19 experts participating to 6 workpackages. The fields which are covered by the consensus on adrenal insufficiency include epidemiology, screening methods and confirmation of diagnosis, strategies for identifying the cause, replacement therapy, acute adrenal insufficiency, monitoring of patients and patient's education. The strength of the recommendations was graded as strong when using the phrase "we recommend" or weak when using the phrase "we suggest". Quality of the evidence of recommendations was graded such as + denotes very low quality of evidence, ++ , low quality; +++ , moderate quality and ++++ , high quality. The manuscripts were reviewed by independent French experts.

\section{Handbook}

\subsection{Epidemiology of primary and secondary adrenal insufficiency: prevalence and incidence, acute adrenal insufficiency, long-term morbidity and mortality [1]}

The prevalence of primary adrenal insufficiency is estimated at between $82-144 /$ million, with auto-immunity being the most common cause in adults and genetic causes, especially enzyme defects, being the most common cause in children. The prevalence of secondary adrenal deficiency is estimated to be between 150-280/million. The most frequent occurrence is believed to be corticosteroid-induced insufficiency, despite the incidence of clinically relevant deficiency after cessation of glucocorticoid treatment being widely debated. Data on mortality in adrenal insufficiency are contradictory, with studies from Sweden suggesting a two-fold increase in comparison to the general population, but this is not consistently reported in all studies. However, increased mortality has been consistently reported in young patients, associated with infection and/or acute adrenal 


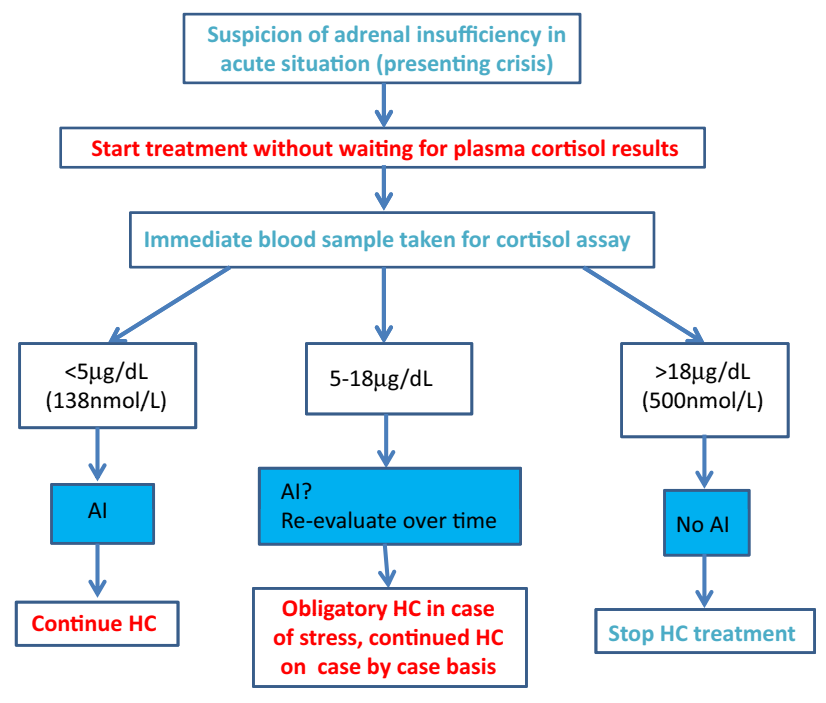

Fig. 1. Algorithm for exploring the hypothalamic pituitary adrenal axis in acute situations.

insufficiency. Acute adrenal deficiency (adrenal crisis) occurs in primary as well as secondary adrenal insufficiency. Its incidence, mostly determined in retrospective studies, is estimated in Europe at $6-8 / 100$ patients/year. A prospective study reported 0.5 deaths $/ 100$ patient-years from adrenal crisis. Long-term morbidity of adrenal insufficiency is not well-established, the increased cardiovascular risk or bone demineralization which are not consistently reported may also be due to a supraphysiological glucocorticoid replacement therapy. However, alteration in quality of life, both in physical and mental health components, has been demonstrated by several studies in both primary and secondary adrenal insufficiency.

\subsection{Screening methods and confirmation of diagnosis [2]}

A diagnosis of adrenal insufficiency should be suspected in the presence of a number of non-specific symptoms (fatigue, anorexia, weight loss, hypotension, hyponatremia and hyperkalemia amongst adrenal causes of insufficiency). The diagnosis should be considered in case of pituitary disease or a state of shock. Treatment should be commenced immediately without waiting for confirmation from biochemical tests, which rely on cortisol level at 8 am (expected to be lower) and on ACTH level (that is expected to be high in the case of primary adrenal insufficiency). If these tests are inconclusive, a Synacthen test should be carried out. The threshold limits are provided as a guide (Fig. 1). Low plasma cortisol and normal to low plasma ACTH indicates a pituitary origin for the deficiency. In this situation, the Synacthen test can give a false normal result, and if adrenal insufficiency is strongly suspected, an insulin hypoglycemia test or a metyrapone (Metopirone) test should be carried out in non acute situations (Fig. 2). In children younger than 2 years, hypoglycemia, dehydration and convulsions are frequently observed and in young girls, virilization is suspect of adrenal insufficiency. The circadian rhythm of cortisol is not present until after 4 months of age and the Synacthen test is the only one that is feasible. In children older than 2 years, the signs and diagnosis methods are the same as in the adult. Cessation of corticosteroid treatment is a frequent circumstance however there is little published data and no evidence for definitive guidelines. After ceasing a short period of corticosteroid treatment, patient

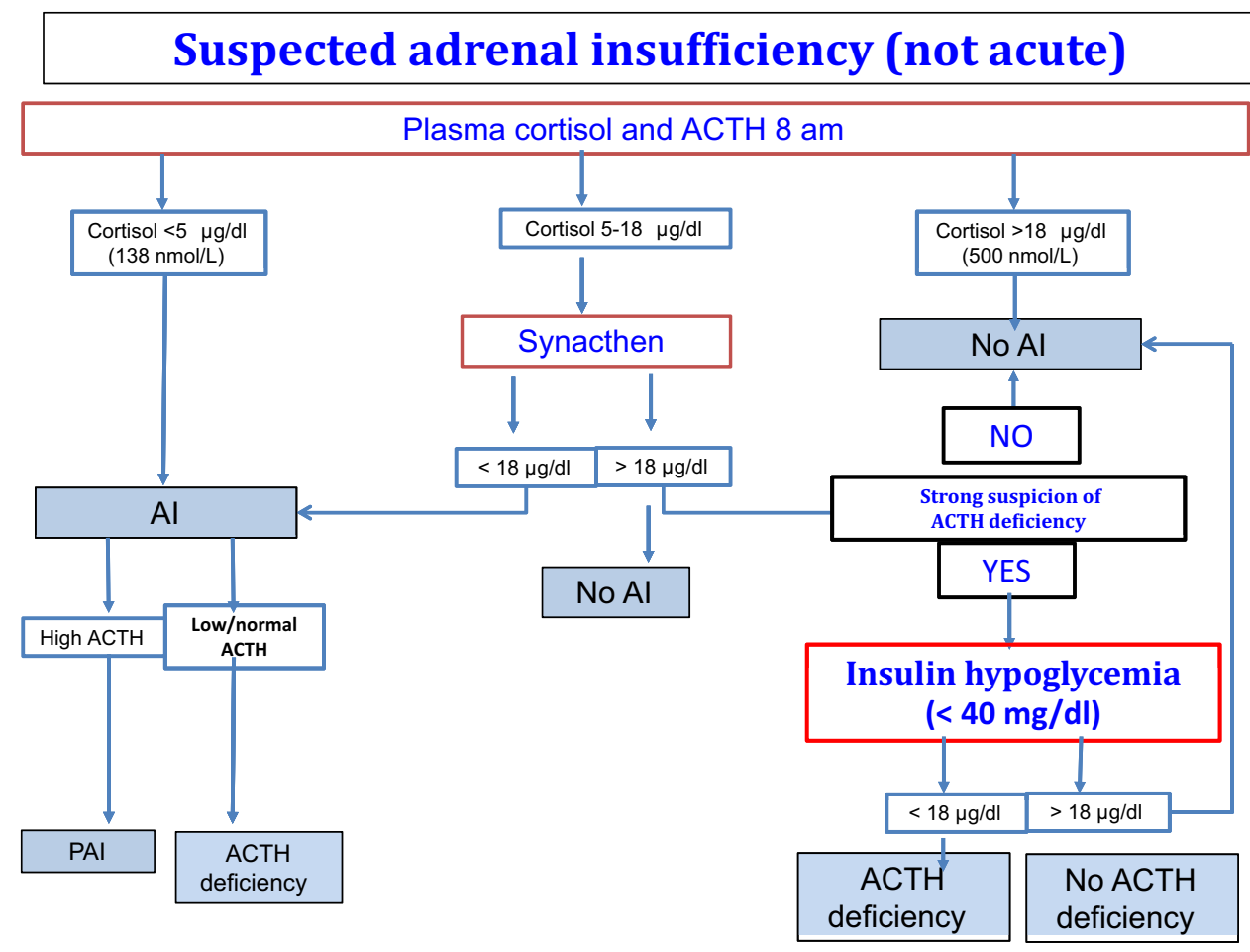


education is all that is required. After longer treatment, consensus leaves the choice up to the physician, between educating the patient and prescribing hydrocortisone in case of stress, or prescribing low daily dose hydrocortisone and evaluating the ACTH axis over time until normal function is recovered.

R2-1: a diagnosis of primary adrenal insufficiency (PAI) should be suspected in cases of:

- asthenia, weight loss, dehydration, hypotension, fever, abdominal pains, nausea and hyperpigmentation;

- patients at high risk of PAI (type 1 diabetes, auto-immune dysthyroidism, bilateral adrenal metastases);

- patients in an "acute" context: unexplained collapse, hypotension, vomiting or diarrhea;

- strong recommendation. Level of evidence: +++ .

R2-2: a diagnosis of ACTH insufficiency should be suspected in the case of symptoms that suggest primary adrenal insufficiency (fatigue, hypotension, nausea, vomiting), with the exception of hyperpigmentation.

Strong recommendation. Level of evidence ++.

R2-3: diagnosis of ACTH insufficiency should also be systematically examined, even in patient with few or no symptoms, in patients with hypothalamic-pituitary disorders: tumors, inflammatory disease or infiltrative disease, surgery in this region, cranial trauma or radiotherapy. This diagnosis can be re-examined at regular intervals.

Strong recommendation. Level of evidence ++ .

R2-4: replacement therapy should be started in ACTH insufficiency as a consequence of surgical treatment for Cushing's syndrome or surgery for a cortisol secreting adrenal tumor. Hydrocortisone treatment in this case should be commenced in the perioperative period, before confirming or eliminating the diagnosis at a later time.

Strong recommendation. Level of evidence: +++ .
R2-5: in the newborn and baby, we recommend examination for (i) primary adrenal insufficiency when patients present with abnormal external genitalia, episodes of hypoglycemia, neonatal cholestatic jaundice, loss of weight, dehydration; (ii) ACTH deficiency when patients present with midline defects, micropenis, cryptorchidism, episodes of hypoglycemia, neonatal cholestatic jaundice.

Strong recommendation. Level of evidence: +++ .

R2-6: in older children and adolescents, we recommend examination for primary adrenal insufficiency or ACTH insufficiency in patients who present with the same signs as adult patients (R2-1, R2-2, R2-3) or with clinical signs of hyperandrogenism to screen for a pure virilizing form of congenital adrenal hyperplasia.

Strong recommendation. Level of evidence: +++ .

R2-7: primary adrenal insufficiency should be considered in patients presenting with hyponatremia, hyperkalemia or unexplained episodes of fasting hypoglycemia.

Strong recommendation. Level of evidence: +++ .

R2-8: ACTH insufficiency should be suspected in patients presenting with hyponatremia or episodes of unexplained hypoglycemia. Hyperkalemia is not included in the manifestations of ACTH insufficiency.

Strong recommendation. Level of evidence: +++ .

R2-9: in acute or emergency situations, a cortisol concentration below $500 \mathrm{nmol} / \mathrm{L}(18 \mu \mathrm{g} / \mathrm{dL})$ should be indicative of adrenal insufficiency and therefore hydrocortisone replacement should be commenced.

Strong recommendation. Expert opinion. 
R2-10: replacement therapy for primary adrenal insufficiency or ACTH insufficiency must be commenced as soon as the diagnosis is suspected and continued until the diagnosis is confirmed or excluded.

Strong recommendation. Level of evidence +++.

R2-11: replacement therapy for ACTH insufficiency should be initiated in the case of surgical treatment for Cushing's syndrome or for an adrenal tumor secreting cortisol, with the treatment started in the perioperative period before later confirmation or exclusion of the diagnosis.

Strong recommendation. Level of evidence: +++ .

R2-12: the diagnosis of primary adrenal insufficiency rests on evidence of low basal plasma cortisol levels and/or low cortisol levels in a stimulation test, and an elevated level of ACTH (see R2-17, R2-21, R2-25).

Strong recommendation. Level of evidence: +++ .

R2-13: after establishing a diagnosis of primary adrenal insufficiency, we recommend that patients are examined for mineralocorticoid deficiency by assays for plasma renin (elevated) and aldosterone (low).

Strong recommendation. Level of evidence: ++ .

R2-14: diagnosis of ACTH insufficiency relies on evidence of low cortisol in the basal state and/or during a stimulation test, and an ACTH level that is not elevated and thus not adapted to the low level of cortisol.

Strong recommendation. Level of evidence: +++ .
R2-15: certain clinical situations cause elevated cortisol levels: estrogen administration, pregnancy and all acute intercurrent diseases. In these situations, diagnosis must rest on higher threshold levels of cortisol and/or on a group of assumptions (case history, ACTH and renin levels).

Strong recommendation. Level of evidence: +++ .

R2-16: assay for urinary free cortisol should not be used in the diagnosis of adrenal insufficiency.

Strong recommendation. Level of evidence: +++ .

R2-17: the disparity in cortisol measured by different kits/assay methods makes it impossible to define universal threshold values. Nevertheless, guidelines can be proposed for morning cortisol levels measured at 7-8 am:

- levels above $18 \mu \mathrm{g} / \mathrm{dL}$ (500 $\mathrm{nmol} / \mathrm{L}$ ) make the diagnosis of adrenal insufficiency unlikely;

- levels less than $5 \mu \mathrm{g} / \mathrm{dL}$ (138 $\mathrm{nmol} / \mathrm{L}$ ) make the diagnosis of adrenal insufficiency very likely;

- in the intermediate zone, between 5 and $18 \mu \mathrm{g} / \mathrm{dL}(138-500 \mathrm{nmol} / \mathrm{L})$, it is necessary to perform a stimulation test.

Weal recommendation. Expert opinion.

R2-18: in babies, the absence of circadian rhythm for cortisol secretion in the first months of life means that baseline cortisol assays need to be repeated and treatment needs to be commenced based on probability of adrenal insufficiency (if cortisol level is low), and that a later Synacthen test will be required.

Weak recommendation. Level of evidence: ++ .

R2-19: a Synacthen test can be performed (i) as first line testing or (ii) as second line testing after basal cortisol measurement, where basal cortisol levels neither confirm nor rule out adrenal insufficiency.

Strong recommendation. Level of evidence: ++. 
R2-20: the Synacthen test normally uses $250 \mu \mathrm{g}$ of Synacthen (or $125 \mu \mathrm{g}$ in children under 2 years). To increase its sensitivity, a Synacthen test using a lower dose $(1 \mu \mathrm{g})$ was developed. The comparative performance of the $1 \mu \mathrm{g}$ dose to the classic test are controversial. Furthermore, the $1 \mu \mathrm{g}$ dose is not commercially distributed and needs to be prepared at the time by the user, which poses both methodological and regulatory problems. Overall, the available comparative studies do not clearly show superiority of the $1 \mu \mathrm{g}$ test over the $250 \mu \mathrm{g}$ test.

$$
\text { Level of evidence: +++. }
$$

R2-21: if the Synacthen test shows an insufficient stimulation of cortisol, that is a level lower than $18 \mu \mathrm{g} / \mathrm{dL}$ ( $500 \mathrm{nmol} / \mathrm{L}$ ) measured 30 or $60 \mathrm{~min}$ after injection, the diagnosis of adrenal insufficiency can be accepted and it is not necessary to perform further tests.

Weak recommendation. Level of evidence: + .

R2-22: the Synacthen test can give false normal results in situations where ACTH insufficiency is recent $(<4$ weeks after pituitary surgery, cranial trauma) or in the case of partial ACTH insufficiency. If the Synacthen test is normal but clinical signs suggest ACTH insufficiency and/or the clinical situation necessitates certainty regarding the ACTH axis (where other anterior pituitary deficiencies are identified), we recommend performing an insulin hypoglycemia or metopirone test.

Strong recommendation. Level of evidence: ++.

R2-23: insulin hypoglycemia is the reference test for confirming or excluding ACTH insufficiency in adults and in older children. It is recommended to perform the test if basal cortisol levels are in the intermediate zone, when the
Synacthen test is normal but clinical signs are suggestive of ACTH insufficiency or where diagnostic certainty is required. The insulin hypoglycemia test can also be done at the same time as examination of the somatotropin axis, where this is required.

Strong recommendation. Level of evidence: ++ .

R2-24: insulin hypoglycemia test should be performed in a specialized hospital setting. It is contra-indicated in cases of seizures, coronary artery disease, where there is a history of stroke or in advanced age. In pediatric patients, it is contraindicated in babies and very small infants.

Strong recommendation. Level of evidence: +++ .

R2-25: a peak of cortisol $>18 \mu \mathrm{g} / \mathrm{dL}(500 \mathrm{nmol} / \mathrm{L})$ (or above the threshold defined by the laboratory) after insulin hypoglycemia where blood glucose reached $<0.40 \mathrm{~g} / \mathrm{L}(2.2 \mathrm{mmol} / \mathrm{L})$ leads to exclusion of ACTH insufficiency.

Strong recommendation. Level of evidence: ++.

R2-26: the Metopirone test (short protocol) or the $\mathrm{CRH}$ test can be employed where an insulin hypoglycemia test is contra-indicated.

Weak recommendation. Levzel of evidence: ++.

R2-27: in case of continued doubt regarding possible latent ACTH insufficiency, we recommend that patients be educated on the prevention of ACTH insufficiency in acute situations, are given a prescription for hydrocortisone (oral and/or injectable) to use in case of intercurrent conditions.

Weak recommendation. Expert opinion.

R2-28: in adults, no monitoring is required after undergoing corticosteroid treatment of short duration (less than 3 weeks).

Weak recommendation. Expert opinion. 
R2-29: in adults, information on warning signs and alerting of physicians involved in the patient's care is sufficient where corticosteroid treatment was for less than 3 months. In the absence of clinical signs, no assays are recommended.

Weak recommendation. Expert opinion.

R2-30: in adults, after treatments longer than 3 months, individual cases need to be carefully considered based on the duration of treatment, the cumulative dose, the presence of signs of hypercortisolism and/or symptoms that are suggestive of adrenal insufficiency (particularly asthenia). Patient education needs to be provided and their physicians need to be informed.

Weak recommendation. Expert opinion.

R2-31: in adult patients, two options are suggested, without sufficient evidence being available to recommend one approach over the other:

- systematic prescription of hydrocortisone, $10-15 \mathrm{mg} /$ day $\left(8-10 \mathrm{mg} / \mathrm{m}^{2} /\right.$ day) taken in 1-2 doses, until the restoration of cortisol secretion, or;

- patient education and prescription of hydrocortisone to be taken only in case of stress.

Weak recommendation. Expert opinion.

R2-32: evaluation of ACTH function should be performed in parallel-assay of cortisol at 8 am and in cases where the result is borderline after Synacthen stimulation, in general after cessation of treatment with synthetic corticosteroid with the aim of screening for patients who will benefit from continued replacement therapy with hydrocortisone. In case of known ACTH deficiency, assay of basal cortisol at 8 am (alternatively after Synacthen) can be repeated at regular intervals (every 3-6 months) until recovery of normal ACTH function.

Weak recommendation. Expert opinion.
R2-33: in children, in the absence of data that predict the occurrence and duration of adrenal insufficiency after corticosteroid therapy and in view of the existence of severe forms of acute adrenal insufficiency, the following approach is suggested:

- in cases of corticosteroid treatment of less than 3-week duration, it is not necessary to prescribe a switch to hydrocortisone treatment, except in cases where there is a high risk of acute adrenal insufficiency (severe infection, surgery) likely to occur in the days-weeks following cessation of corticosteroid treatment. In this situation, we suggest treatment with hydrocortisone (dose used in stress situations) and re-evaluation of ACTH function at a later time;

- in cases of corticosteroid treatment of more than three weeks duration, we suggest patient education and education of the parents on the signs of acute adrenal insufficiency, alerting of the physicians and evaluation of ACTH function (cortisol and ACTH at $8 \mathrm{am} \pm$ Synacthen test if the assay results are inconclusive).

Weak recommendation. Expert opinion.
R2-34: in children, two options can be suggested for cessation of corticosteroid therapy when the dose of corticosteroid reaches an equivalent prednisone dose of $3 \mathrm{mg} / \mathrm{m}^{2} /$ day or less:

- either a systematic switch to hydrocortisone $\left(8-10 \mathrm{mg} / \mathrm{m}^{2} /\right.$ day in children and $10-12 \mathrm{mg} / \mathrm{m}^{2} /$ day in babies) taken in two doses until evaluation of ACTH function is performed, which would allow hydrocortisone treatment to be stopped when normal secretion of cortisol is returned $(>18 \mu \mathrm{g} / \mathrm{dL}$ or $500 \mathrm{nmol} / \mathrm{L})$. It is not necessary to perform a Synacthen test if $8 \mathrm{am}$ cortisol levels are $<5 \mu \mathrm{g} / \mathrm{dL}$ (or $138 \mathrm{nmol} / \mathrm{L}$ ), or;

- a prescription for hydrocortisone uniquely in case of situations with a risk of acute adrenal insufficiency, only if 8 am cortisol values at cessation of corticosteroid treatment are higher than $5 \mu \mathrm{g} / \mathrm{dL}(138 \mathrm{nmol} / \mathrm{L})$. ACTH function is then re-evaluated at regular intervals until recovery of normal function. 
R2-35: the study group encourages endocrinologists to declare confirmed cases of clinical adrenal insufficiency, as a result of corticosteroid therapy, to pharmacovigilance authorities with a reminder that there is a legal obligation to report adverse effects as with any other drug.

Weak recommendation. Expert opinion.

\subsection{Strategies for identifying the cause of adrenal insufficiency: diagnostic algorithms in adults and children (Figs. 3-5) (Tables 1 and 2) [3]}

In the majority of cases in adults, primary adrenal insufficiency is of auto-immune origin. It is therefore recommended that a test for anti-21-hydroxylase antibodies be performed as part of initial testing. If the auto-immune origin is confirmed, in the case of clinical signs that are indicative of the possibility of other auto-immune disorders, it is recommended to then test for auto-immune polyendocrinopathy type 1 (APECED syndrome). An adrenal CT scan should be performed if autoantibody tests are negative, or where other clinical signs suggest a rarer etiology but may require rapid commencement of patient care (tuberculosis, other infections, tumors, hemorrhage, etc.). In the case of negative results of the first two tests, assay for very long chain fatty acids is recommended in males, particularly in young subjects (Figs. 3 and 5 Table 1). In the case of isolated corticotropin (ACTH) insufficiency, in both adults and children, it is recommended to first eliminate iatrogenic origins for the disease (corticosteroid treatment-induced or after treatment for Cushing's syndrome). If all of these etiologies are excluded, exploration of other pituitary axes by hypothalamicpituitary MRI should be done (Table 2). In neonates, primary adrenal insufficiency or ACTH insufficiency is most often due

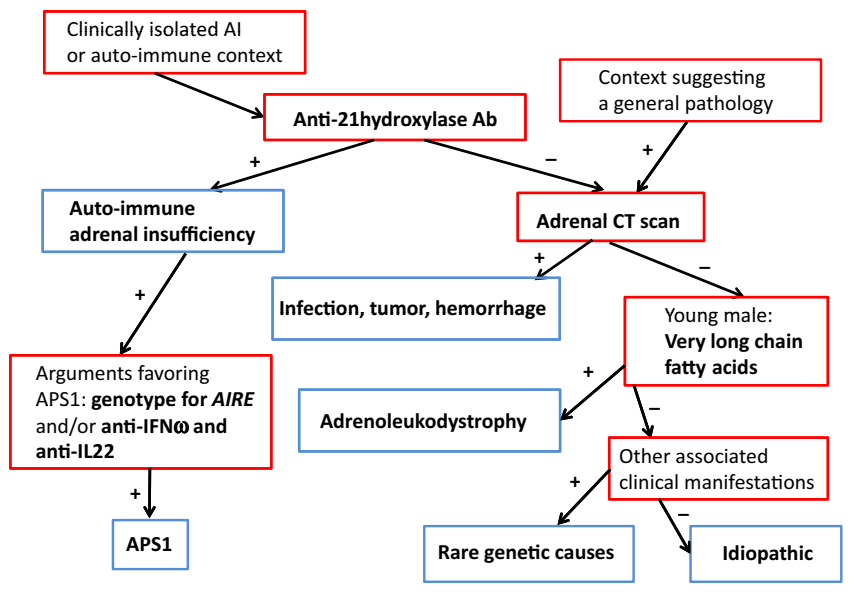

Fig. 3. Decision tree for diagnosing etiology of primary adrenal insufficiency in the adult.

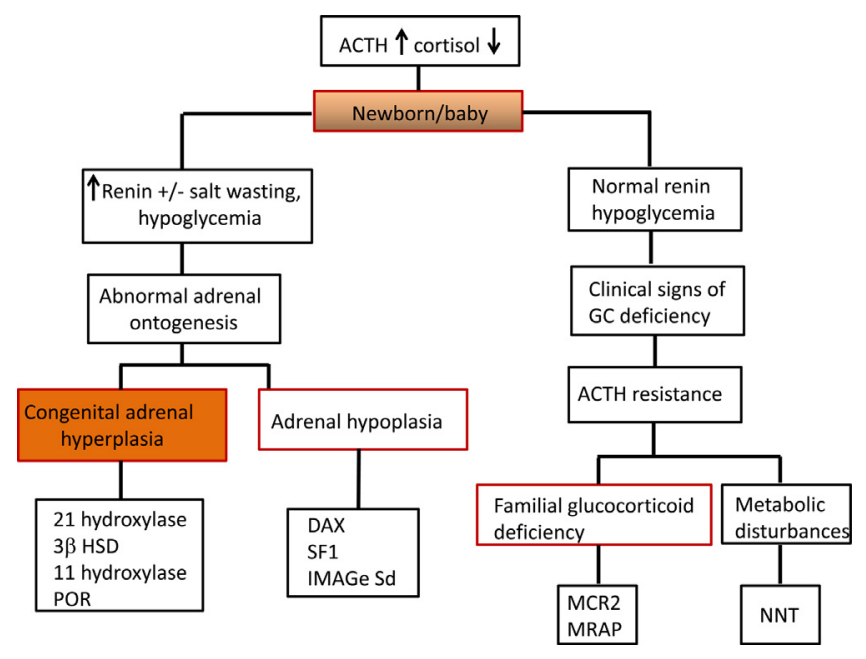

Fig. 4. Decision tree for diagnosing etiology of primary adrenal insufficiency in the new born and baby.

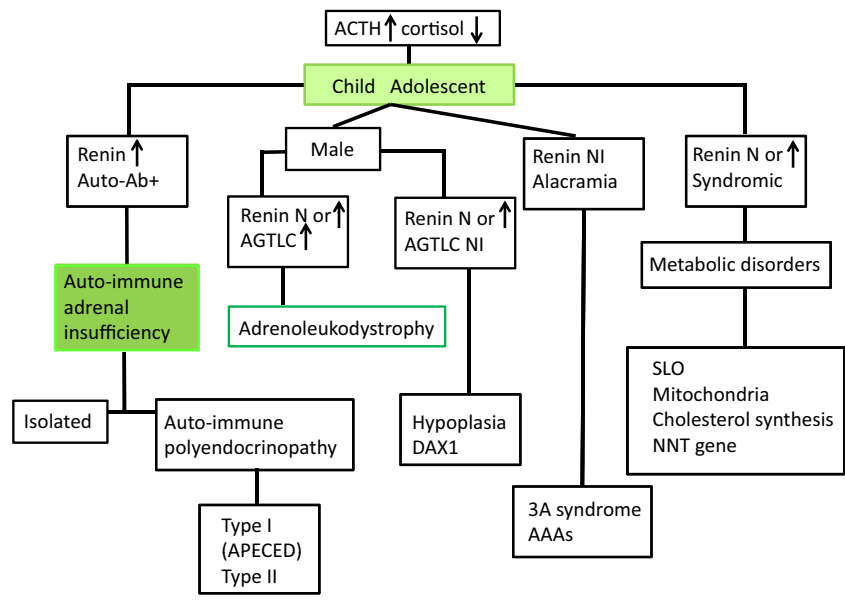

Fig. 5. Decision tree for diagnosing etiology of primary adrenal insufficiency in the child and adolescent.

to a genetic anomaly, with congenital adrenal hyperplasia being the principal etiology (Figs. 4 and 6 Table 3). In older children, testing for an auto-immune etiology is needed. In the case of negativity for auto-antibodies, depending on associated clinical signs, other genetic causes should be considered including adrenoleukodystrophy in boys (Fig. 6). In the case of congenital ACTH insufficiency, testing for other pituitary manifestations should be carried out to aid in further molecular analyses of genes that are implicated in pituitary development (Fig. 6).

R3-1: we recommend examination for the etiology of Al to optimise its management and to avoid overlooking causal pathologies that can be treated.

Strong recommendation. Expert opinion. 
Table 1

Principal etiologies in adult primary adrenal insufficiency and their clinical characteristics.

\begin{tabular}{|c|c|c|c|}
\hline Etiology & Origin & $\begin{array}{l}\text { Clinical manifestations associated } \\
\text { with adrenal insufficiency (in order } \\
\text { of frequency) }\end{array}$ & Diagnostic criteria \\
\hline \multicolumn{4}{|l|}{ Auto-immune } \\
\hline $\begin{array}{l}\text { APS1 } \\
\text { (APECED) }\end{array}$ & $\begin{array}{l}\text { Monogenic } \\
\text { Mutations of AIRE gene } \\
\text { Polygenic }\end{array}$ & $\begin{array}{l}\text { Candidiasis (83-100\%) } \\
\text { Hypoparathyroidism (79-93\%) } \\
\text { AI (60-70\%) } \\
\text { Ovaritis (60\%) } \\
\text { Dental enamel hypoplasia (77\%) } \\
\text { Alopecia (29-37\%) } \\
\text { Keratitis (12-35\%) } \\
\text { Malabsorption (15-18\%) } \\
\text { Hepatitis (12-20\%) } \\
\text { Gastritis (13-15\%) } \\
\text { Vitiligo (12-13\%) } \\
\text { Thyroiditis (3-10\%) } \\
\text { Diabetes (type 1) (2-12\%) } \\
\text { Hypophysitis (7\%) } \\
\text { Interstitial nephritis, obliterative bronchiolitis, febrile } \\
\text { cutaneous rash (more rare)... } \\
\text { Thyroiditis (65-75\%) } \\
\text { Diabetes type } 1(50-60 \%) \\
\text { AI (19-40\%) } \\
\text { Ovaritis (5-10\%) } \\
\text { Gastritis (5-29\%) }\end{array}$ & $\begin{array}{l}\text { At least } 2 \text { components of Whitaker triad } \\
\text { ( } 1 \text { alone if siblings affected): candidiasis, AI } \\
\text { with positive Ab anti-21- hydroxylase, } \\
\text { hypoparathyroidism: sequencing of AIRE } \\
\text { gene; anti-interferon- } \omega \text { or anti-IL } 22 \mathrm{AB} \text { if } \\
\text { available } \\
\text { AI associated with other autoimmune } \\
\text { pathologies, principally } \\
\text { thyroiditis } \\
\text { and/or type } 1 \text { diabetes } \\
\text { Anti-21- hydroxylase } \mathrm{Ab}\end{array}$ \\
\hline APS2 & $\begin{array}{l}\text { HLA: class II: DR3-DQ2, DR4-DQ8, DRB1*0404 and *0301; } \\
\text { class I: DR3-B8 }\end{array}$ & $\begin{array}{l}\text { Celiac disease }(3-10 \%) \\
\text { Vitiligo }(10-20 \%)\end{array}$ & \\
\hline Isolated & Other molecules: linked to CMH: MICA, CIITA; co-stimulators of & Alopecia $(2-6 \%)$ & Anti-21- hydroxylase Ab \\
\hline auto-immune & CMH: CTLA-4, PTPN22; linked to Ly B: FcRL3 promoter; innate & Hypoparathyroidism (3\%) & Context of familial autoimmune \\
\hline AI & immunity: CLEC16A, NALP1; vitamin D receptor... & Hypophysitis (2\%) & pathologies \\
\hline Infectious & Polygenic (cf APS2) & & \\
\hline Bacterial & $\begin{array}{l}\text { Tuberculosis (Mycobacterial), } \\
\text { Haemophilus influenzae, Syphilis } \\
\text { (Treponema pallidum) }\end{array}$ & $\begin{array}{l}\text { Other systemic manifestations of the } \\
\text { pathology }\end{array}$ & $\begin{array}{l}\text { Adrenal CT, IDR, IGRA, culture, } \\
\text { PCR }\end{array}$ \\
\hline Viral & HIV, CMV, HSV... & & \\
\hline
\end{tabular}


Table 1

(Continued)

\begin{tabular}{|c|c|c|c|}
\hline Etiology & Origin & $\begin{array}{l}\text { Clinical manifestations associated } \\
\text { with adrenal insufficiency (in order } \\
\text { of frequency) }\end{array}$ & Diagnostic criteria \\
\hline Parasitic & $\begin{array}{l}\text { Trypanosoma african (Trypanosoma } \\
\text { brucei) }\end{array}$ & & \\
\hline Fungal & $\begin{array}{l}\text { Pneumocystis carinii, } \\
\text { histoplasmosis, cryptococcosis, } \\
\text { cocciodiomycosis, blastomycosis }\end{array}$ & Opportunistic infections & \\
\hline Hemorrhagic & $\begin{array}{l}\text { Anticoagulants, inhibitor of tyrosine } \\
\text { kinase (sunitibib) } \\
\text { Antiphospholipid antibody syndrome } \\
\text { Meningococcal sepsis } \\
\text { (Waterhouse-Friderichsen) } \\
\text { Disseminated intravascular } \\
\text { coagulation }\end{array}$ & Acute adrenal insufficiency & Adrenal CT (hemorrhage) \\
\hline $\begin{array}{l}\text { Post-surgical } \\
\text { Bilateral } \\
\text { adrenalectomy }\end{array}$ & $\begin{array}{l}\text { Uncontrolled Cushing syndrome, } \\
\text { bilateral adrenal masses, bilateral } \\
\text { phaeochromocytoma }\end{array}$ & & \\
\hline $\begin{array}{l}\text { Tumoral: } \\
\text { secondary, } \\
\text { rarely primary }\end{array}$ & $\begin{array}{l}\text { Bilateral metastases pulmonary, } \\
\text { renal, gastric, breast, colon, } \\
\text { pancreatic, melanoma, lymphoma }\end{array}$ & & $\mathrm{CT}$ \\
\hline Infiltrative & $\begin{array}{l}\text { Amylosis, hemochromatosis, } \\
\text { sarcoidosis, xanthogranulomatosis }\end{array}$ & & \\
\hline Drug-related & $\begin{array}{l}\text { Ketoconazole, fluconazole, } \\
\text { etomidate, metyrapone } \\
\text { Phenobarbital, phenytoin, } \\
\text { rifampicine, } \\
\text { Mitotane } \\
\text { Anti-CTLA4 (ipilimumab) } \\
\text { associated or not with anti-PD1 } \\
\text { (nivolumab, pembrolizumab) }\end{array}$ & $\begin{array}{l}\text { Inhibition of cytochrome } \\
\text { P450-dependent enzymes (CYP11A1, } \\
\text { CYP11B1) } \\
\text { Induction of cytochrome } \\
\text { P450-dependent enzymes (CYP2B1, } \\
\text { CYP2B2, CYP3A4) increasing } \\
\text { cortisol metabolism } \\
\text { Cytotoxic mechanism } \\
\text { Auto-immune mechanism }\end{array}$ & \\
\hline $\begin{array}{l}\text { Genetic (Table } 3 \\
\text { pediatric) }\end{array}$ & $\begin{array}{l}\text { Adrenoleukodystrophy (mutation of } \\
A B C D 1 \text { ) }\end{array}$ & Table 3, pediatric & \\
\hline
\end{tabular}

IGRA: interferon- $\gamma$ release assay: QuantiFERON-Tb Gold in Tube ${ }^{\circledR}$ (Cellestis Ld. Carnegie, Victoria, Australia) or T-SPOT.TB @ (Oxford Immunotec Ltd., Abingdon, UK). 
Table 2

Etiologies of ACTH insufficiency in adults.

\begin{tabular}{|c|c|c|c|}
\hline Etiology & $\begin{array}{l}\text { Pathophysiological } \\
\text { mechanisms }\end{array}$ & $\begin{array}{l}\text { Clinical manifestations associated with adrenal } \\
\text { insufficiency }\end{array}$ & Diagnostic criteria \\
\hline \multicolumn{4}{|l|}{ Iatrogenic } \\
\hline $\begin{array}{l}\text { Post-corticosteroid, or post-treatment of } \\
\text { Cushing's syndrome }\end{array}$ & $\begin{array}{l}\text { Inhibition of ACTH } \\
\text { axis }\end{array}$ & Isolated ACTH insufficiency & \multirow[t]{8}{*}{ Context dependent } \\
\hline Opioids & & Gonadotropin insufficiency & \\
\hline Antidepressants (imipramine) & \multirow[t]{6}{*}{ ACTH deficiency } & & \\
\hline Antipsychotics (chlorpromazine) & & & \\
\hline Hypophysitis iatrogenic: & & & \\
\hline Interferon-ribavirine & & & \\
\hline Anti-CTLA4 (ipilimumab) \pm associated & & ACTH deficiency sometimes indicative & \\
\hline $\begin{array}{l}\text { with anti-PD1 (nivolumab, } \\
\text { pembrolizumab) }\end{array}$ & & $\begin{array}{l}\text { Frequently associated with TSH } \\
\text { deficiency } \pm \text { gonadotropin, GH deficiency, } \\
\text { rarely with diabetes insipidus or SIADH }\end{array}$ & \\
\hline \multicolumn{4}{|l|}{ Tumors } \\
\hline $\begin{array}{l}\text { Hypothalamic: craniopharyngiomas, } \\
\text { metastases (lung, breast) }\end{array}$ & CRH deficiency & $\begin{array}{l}\text { Other anterior or posterior pituitary deficiencies, } \\
\pm \text { other clinical manifestations linked to the } \\
\text { causal pathology }\end{array}$ & MRI, context dependent \\
\hline $\begin{array}{l}\text { Pituitary: macroadenomas, cysts, } \\
\text { craniopharyngiomas, ependymomas, } \\
\text { meningiomas, carcinomas (rarely) }\end{array}$ & ACTH deficiency & & \\
\hline $\begin{array}{l}\text { Pituitary surgery or radiotherapy (pituitary } \\
\text { tumors, cerebral tumors, in the } \\
\text { nasopharyngeal region, leukemias) }\end{array}$ & $\begin{array}{l}\text { Deficiency in CRH } \\
\text { and/or ACTH }\end{array}$ & Other anterior or posterior pituitary deficiencies & Context dependent \\
\hline \multicolumn{4}{|l|}{ Hypophysitis primary } \\
\hline Lymphocytic & $\begin{array}{l}\text { Deficiency in CRH } \\
\text { and/or ACTH }\end{array}$ & $\begin{array}{l}\text { ACTH deficiency, sometimes isolated, } \pm \\
\text { diabetes insipidus and other anterior/posterior } \\
\text { pituitary deficiencies, headache, vision } \\
\text { problems, other associated auto-immune } \\
\text { diseases }\end{array}$ & $\begin{array}{l}\text { MRI, context dependent } \\
\text { (females, peri-partum) }\end{array}$ \\
\hline Granulomatous & & Headache, vision problems, other & MRI, histology \\
\hline Xanthomatous & & anterior/posterior pituitary deficiencies & MRI histolooy hionsy of \\
\hline $\begin{array}{l}\text { IgG4 hypophysitis (IgG4 fibro-sclerosing } \\
\text { disease) }\end{array}$ & & $\begin{array}{l}\text { Headache, vision problems, other } \\
\text { anterior/posterior pituitary deficiencies, other } \\
\text { systemic effects (retroperitoneal fibrosis, } \\
\text { sialadenitis, dacryoadenitis, adenopathies, } \\
\text { nephritis...) }\end{array}$ & $\begin{array}{l}\text { MRI, histology, biopsy of } \\
\text { target organ, IgG4 assay, } \\
\text { context (males, mature } \\
\text { age) }\end{array}$ \\
\hline \multicolumn{4}{|l|}{ Hypophysitis } \\
\hline $\begin{array}{l}\text { Secondary to systemic pathology: } \\
\text { infectious: tuberculosis, syphilis, } \\
\text { actinomycosis, meningitis, abscess; } \\
\text { inflammatory: sarcoidosis, ANCA } \\
\text { vasculitis, Wegener; infiltrative: } \\
\text { hemochromatosis, amylosis, histiocytosis }\end{array}$ & & $\begin{array}{l}\text { Headache, visual problems, other anterior or } \\
\text { posterior pituitary deficiencies, } \pm \text { other clinical } \\
\text { manifestations linked to the causal pathology }\end{array}$ & \\
\hline \multicolumn{4}{|l|}{ Vascular } \\
\hline Pituitary apoplexy & ACTH deficiency & $\begin{array}{l}\text { Severe headaches, vision problems, nausea, } \\
\text { vomiting, other anterior/posterior pituitary } \\
\text { deficiencies }\end{array}$ & MRI \\
\hline Sheehan syndrome & & $\begin{array}{l}\text { Hemorrhage in childbirth/delivery, headaches, } \\
\text { vision problems, nausea, vomiting, other } \\
\text { anterior/posterior pituitary deficiencies }\end{array}$ & MRI, context peri-partum \\
\hline \multicolumn{4}{|l|}{ Traumatic } \\
\hline Cranial trauma & $\begin{array}{l}\mathrm{CRH} \text { and/or ACTH } \\
\text { deficiency (from } \\
\text { pituitary } \\
\text { hypoperfusion) }\end{array}$ & $\begin{array}{l}\text { Other anterior/posterior pituitary deficiencies } \\
\text { (often gonadotropin and } \mathrm{GH} \text { ) }\end{array}$ & Context dependent \\
\hline Genetic (Fig. 3, pediatric) & & & \\
\hline
\end{tabular}

Adapted from Charmandari, 2014.

\subsection{Replacement therapy for adrenal insufficiency [4]}

Glucocorticoid replacement is mainly based in France on the use of hydrocortisone, that should be given at the lowest possi-

ble dose, in 2 or 3 intakes per day. Dose monitoring should be based on clinical signs of over or under-replacement: biological markers should not be used on a regular basis. Mineralocorticoid replacement is based on a mean dose of 100 micrograms of 
Table 3

Etiologies of primary adrenal insufficiency in children.

\begin{tabular}{|c|c|c|c|}
\hline Pathology & Gene & OMIM & Associated signs \\
\hline \multicolumn{4}{|l|}{ Abnormal steroidogenesis } \\
\hline Congenital adrenal lipoid hyperplasia & Star & 201710 & 46,XY DSD, gonadal insufficiency \\
\hline P450 side chain cleavage deficiency (P450scc) & CYP11A1 & 118485 & 46,XY DSD, gonadal insufficiency \\
\hline $3 \beta$-hydroxysteroid dehydrogenase $(\mathrm{CAH})$ deficiency & $H S D 3 B 2$ & 201810 & 46,XY DSD and 46,XX DSD, gonadal insufficiency \\
\hline 21-hydroxylase deficiency (CAH) & CYP21A2 & 201910 & 46,XX DSD, hyperandrogenism \\
\hline $11 \beta$-hydroxylase deficiency (CAH) & $C Y P 11 B 1$ & 202010 & 46,XX DSD, hypertension, hyperandrogenism \\
\hline 17-hydroxylase deficiency (CAH) & CYP17A1 & 202110 & 46,XY DSD, hypertension, gonadal insufficiency \\
\hline P450 oxidoreductase deficiency $(\mathrm{CAH})$ & POR & 613571 & $\begin{array}{l}\text { 46,XY DSD, 46,XX DSD, gonadal insufficiency Antley-Bixler } \\
\text { syndrome (bone defects) }\end{array}$ \\
\hline $\begin{array}{l}\text { Aldosterone synthase } \\
\text { Deficiency }\end{array}$ & \multicolumn{2}{|c|}{ Deficiency } & Isolated mineralocorticoid deficiency \\
\hline \multicolumn{4}{|l|}{ Adrenal hypoplasia/dysgenesis } \\
\hline X-linked adrenal hypoplasia & $\begin{array}{l}\text { NROB1 } \\
(D A X 1)\end{array}$ & 300200 & Hypogonadism hypogonadotropic \\
\hline SF1 deficiency & NR5A1 (SF1) & 184757 & 46,XY DSD, gonadal insufficiency \\
\hline IMAGe syndrome & $C D K N 1 C$ & 614732 & $\begin{array}{l}\text { Intra-uterine growth retardation, bone defects, genital } \\
\text { abnormalities, facial dysmorphia, hypercalcemia }\end{array}$ \\
\hline MIRAGE syndrome & SAMD9 & 617053 & $\begin{array}{l}\text { Myelodysplasia, infection, growth retardation, genital } \\
\text { abnormalities, enteropathy }\end{array}$ \\
\hline Pallister-Hall syndrome & GLI3 & 165240 & $\begin{array}{l}\text { Hypothalamic hamartoma, polydactyly, bifid epiglottis, } \\
\text { imperforate anus, genital abnormalities }\end{array}$ \\
\hline Meckel syndrome & MKS1 & 249000 & $\begin{array}{l}\text { Polycystic kidney, cerebral malformations, occipital } \\
\text { encephalocoele, polydactyly, hepatic fibrosis }\end{array}$ \\
\hline Pena-Shokeir syndrome & $\begin{array}{l}\text { DOK7 } \\
\text { RAPSN }\end{array}$ & 208150 & $\begin{array}{l}\text { Arthrogryposis, facial dysmorphia, intra-uterine growth } \\
\text { retardation, camptodactyly, pulmonary hypoplasia, cardiac } \\
\text { malformation, intestinal malrotation }\end{array}$ \\
\hline \multicolumn{4}{|l|}{ ACTH resistance } \\
\hline Familial glucocorticoid deficiency & $\begin{array}{l}M C 2 R \\
M R A P\end{array}$ & 202200607398 & Absence of mineralocorticoid deficiency, large size \\
\hline Triple A syndrome (Allgrove syndrome) & $A A A S$ & 231550 & $\begin{array}{l}\text { Alacrimia, achalasia, deafness, neurological defects, } \\
\text { hyperkeratosis }\end{array}$ \\
\hline Oxidative stress defect & $N N T$ & 614736606448609981 & Affected organs that are rich in mitochondria (myocardiopathy, \\
\hline DNA repair defect & $\begin{array}{l}\text { TXNRD2 } \\
\text { MCM4 }\end{array}$ & & $\begin{array}{l}\text { hypothyroidism, partial GH deficiency) } \\
\text { NK cell deficiency, recurrent viral infections, short stature, } \\
\text { microcephaly }\end{array}$ \\
\hline \multicolumn{4}{|l|}{ Peroxisomal diseases } \\
\hline Adrenoleukodystrophy & $A B C D 1$ & 300100 & $\begin{array}{l}\text { Progressive degenerative neurological damage, deafness, vision } \\
\text { problems, convulsions, accumulation of very long chain fatty } \\
\text { acids }\end{array}$ \\
\hline Infantile Refsum disease & PHYH, PEX7 & 266500 & $\begin{array}{l}\text { Pigmentary retinopathy, deafness, cerebellar ataxia, hypotonia, } \\
\text { growth retardation, intellectual disability }\end{array}$ \\
\hline Zellweger syndrome & $\begin{array}{l}P E X \\
(P E X 1)\end{array}$ & 214100 & $\begin{array}{l}\text { Facial dysmorphia, severe hypotonia, epilepsy, severe } \\
\text { intellectual disability, blindness, deafness, hepatomegaly, } \\
\text { genital abnormalities }\end{array}$ \\
\hline \multicolumn{4}{|l|}{ Mitochondrial cytopathies } \\
\hline Kearns-Sayre syndrome & $\begin{array}{l}\text { Mitochondrial } \\
\text { DNA deletion }\end{array}$ & 530000 & $\begin{array}{l}\text { Progressive ophtalmoplegia, deafness, cardiac abnormalities, } \\
\text { ataxia, intellectual disability, myopathy, hormonal deficiencies, } \\
\text { renal insufficiency }\end{array}$ \\
\hline \multicolumn{2}{|l|}{$\begin{array}{l}\text { Auto-immune diseases } \\
\text { (cf. Adult able) }\end{array}$} & & \\
\hline
\end{tabular}

Adapted from Malikova, 2014.

DSD: disorders of sex development. 


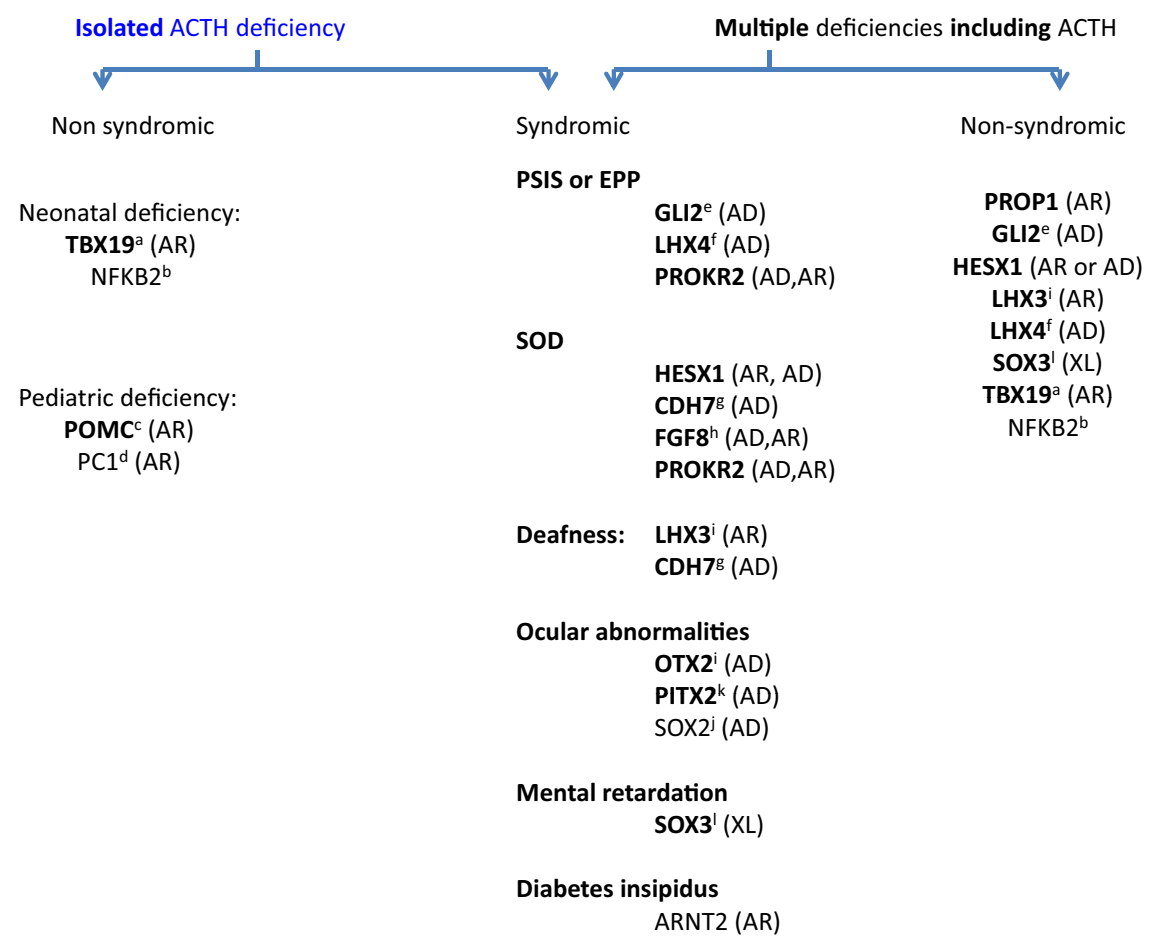

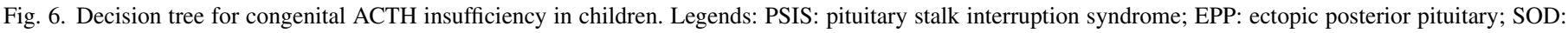

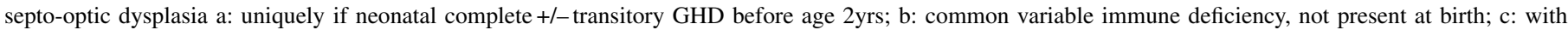

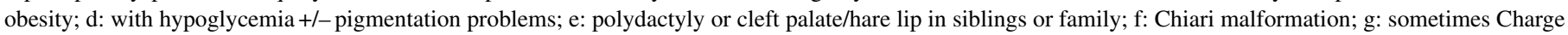
syndrome; h: if holoprosencephaly; i: sometimes abnormality in neck rotation; j: micropthalmia; k: Rieger syndrome; 1 : mental retardation.

R3-2: we recommend assay for anti-21hydroxylase antibodies as first-line testing in adults

Strong recommendation, level of evidence ++ .

R3-3: we suggest that assay for anti-adrenal antibodies be discontinued.

Strong recommendation, level of evidence ++.

R3-4: in young patients with auto-immune adrenal insufficiency, in case of clinical symptoms that are suggestive of auto-immune polyendocrinopathy 1 (APS1) - i.e. candidiasis and hypoparathyroidism, keratitis, alopecia, hypoplasia of dental enamel, malabsorption, ovaritis, hepatitis -, we recommend genotyping for the AIRE gene.

Strong recommendation, level of evidence + .

fludrocortisone, and free sodium intake. Primary adrenal insufficiency but not corticotroph deficiency should be replaced by fludrocortisone. Dose monitoring should be based on clinical signs of over and under-replacement, and the level of renin.
R3-5: we suggest assays for either antiinterferon $\omega$ or anti-IL22 antibodies, if available, in those cases requiring a rapid diagnosis, i.e. those with serious visceral sequelae.

Weak recommendation. Expert opinion.

R3-6: in adult patients, we recommend adrenal CT when tests are negative for anti21-hydroxylase antibodies or immediately in the case of clinical signs suggesting a general pathology that requires urgent management (tuberculosis, hemorrhage, tumor).

Strong recommendation, level of evidence ++ .

R3-7: if an auto-immune etiology is not found, and in the case of a normal adrenal CT, assay for very long chain fatty acids should be carried out, particularly in adolescent males but also in adult male subjects.

Weak recommendation. Expert opinion.

Finally, DHEA can be delivered to women with altered quality of life despite optimal glucocorticoid and mineralocorticoid 
R3-8: in the case of isolated ACTH insufficiency at presentation, previous or current corticosteroid treatment, either by systemic or local administration, should be suspected.

Strong recommendation. Expert opinion.

R3-9: in the absence of previous corticosteroid treatment or previous management of Cushing's syndrome, ACTH insufficiency should be explored. This requires a complete examination of pituitary hormones and morphology (pituitary $M R I$ in the absence of contraindication).

Strong recommendation. Expert opinion.

R3-10: in newborns and babies, in the case of glucocorticoid deficiency \pm mineralocorticoid deficiency, we recommend examination for congenital adrenal hyperplasia by assays for adrenal steroids using LC-MS/MS. In the absence of evidence of enzyme deficiency, we recommend high-speed sequencing of a panel of genes responsible for other rare causes of adrenal insufficiency.

Strong recommendation, level of evidence ++.

R3-11: in newborns and babies, in the case of deficiency restricted to glucocorticoids, we recommend high-speed sequencing of the same panel of genes mentioned above (R3-10).

Strong recommendation, level of evidence ++.

R3-12: in children and adolescents, in the case of glucocorticoid and mineralocorticoid deficiency, we recommend as first-line testing for anti-21-hydroxylase antibodies. In the absence of antibodies, and in males, we recommend assay for very long chain fatty acids to confirm adrenoleukodystrophy. If all tests are negative, examination of $D A X-1$ (NROB1) gene can be carried out prior to studying the panel of genes.

Strong recommendation, level of evidence ++.

replacements. Dose monitoring should be based on plasma levels of DHEA and clinical benefits of the treatment.
R3-13: in children and adolescents, in the case of glucocorticoid deficiency \pm mineralocorticoid deficiency, we recommend that in males examinations performed to confirm a diagnosis of adrenoleukodystrophy, and depending on associated clinical and biochemical signs, high-speed sequencing of the same panel of genes as mentioned above (R3-10) is carried out.

Strong recommendation, level of evidence ++ .

R3-14: in the newborn, diagnosis of ACTH deficiency should be followed with a complete examination of the pituitary as well as examinations for cerebral, ocular and cardiac malformations.

Strong recommendation, level of evidence ++.

R3-15: in the newborn, diagnosis of ACTH deficiency associated with other pituitary deficiencies should be followed by genetic analyses which may be useful for an evolving prognosis. In the presence of mutation of TBX19 gene and neonatal GH deficiency, other axes should be reevaluated around 2 years of age, to confirm reversal of the $\mathrm{GH}$ deficiency.

Strong recommendation. Expert opinion.

R3-16: in children and adolescents, diagnosis of multiple constitutional non-syndromic pituitary deficiencies should be followed by genetic testing in order to advise the family and a screening of family members if necessary.

Strong recommendation; Expert opinion.

R3-17: in children or adolescents, the presence of isolated ACTH deficiency should be followed by examination for immune deficiency and analysis of the NFKB2 gene. If there is associated childhood obesity, testing for POMC gene anomaly should be performed.

Strong recommendation, level of evidence ++.

\subsection{Acute adrenal insufficiency in adults and pediatric patients [5]}

Acute adrenal insufficiency is a serious condition with an estimated frequency of 6 to 8.3 episodes/100 patients/year. 
R4-1: in adults and children, we recommend the use of hydrocortisone as first line treatment of primary or secondary adrenal insufficiency. The treatment is a lifetime treatment except in special cases such as recovery from surgery for hypercortisolism, or after stopping of glucocorticoid treatment.

Strong recommendation, level of evidence ++++ .

R4-2: in adult patients, first generation longacting glucocorticoids (prednisolone, dexamethasone) should not be used except in the case of poor efficacy of hydrocortisone due to its pharmacokinetics. In children, they should not be used except on specialist advice.

Weak recommendation, level of evidence ++.

R4-3: in the adult patient, we recommend the lowest possible replacement dose of hydrocortisone that is tolerated to treat adrenal insufficiency, keeping in mind that a dose of $15-25 \mathrm{mg} /$ day is used as replacement in primary adrenal insufficiency (Addison's disease). (We recommend a lower dose [10-20 mg/day] to substitute for corticotroph deficiency). In children, for primary adrenal insufficiency due to $\mathrm{CAH}$, we recommend a dose of hydrocortisone of $10-18 \mathrm{mg} / \mathrm{m}^{2} /$ day, higher in the neonatal period $\left(20-40 \mathrm{mg} / \mathrm{m}^{2} /\right.$ day during the first month) and in other cases of primary adrenal insufficiency a dose of $8-15 \mathrm{mg} / \mathrm{m}^{2} /$ day.

We recommend a lower dose $\left(8-10 \mathrm{mg} / \mathrm{m}^{2} /\right.$ day) in the case of corticotroph deficiency, with the highest dose in babies prior to weaning.

Strong recommendation, level of evidence +++.

R4-4: in adults and children, we suggest that the dose of hydrocortisone is splitted into 2 or 3 administrations per day, with the highest dose in the morning. A regimen of 3 doses is recommended in babies and young children.

Weak recommendation, level of evidence ++ .

Infection, particularly gastrointestinal infection, is the most frequently reported initiating factor in adults and children but there are multiple other etiologies. Diagnosis is through clinical signs, supported by standard biochemical examinations once adrenal insufficiency is confirmed. Diagnosis can be difficult if the defi-
R4-5: in adults, we do not recommend the use of prolonged release hydrocortisone or hydrocortisone delivered by subcutaneous pump. In children, we do not recommend glucocorticoids other than hydrocortisone, nor hydrocortisone in suspension.

Weak recommendation: expert opinion.

R4-6: in adults, we recommend monitoring of treatment based on clinical signs of overdose or under-dosage. We do not recommend routine use of biochemical markers for adjustment of replacement therapy. In children, we recommend clinical monitoring (growth, puberty) and observation of clinical signs of overdose and under-dosage. We do not recommend routine use of biochemical markers for adjustment of replacement therapy, except in the case of congenital adrenal hyperplasia, where we recommend regular assay of biochemical markers (see National guidelines for diagnosis and treatment of congenital adrenal hyperplasia, [PNDS] 2011).

Strong recommendation, level of evidence +++.

R4-7: we suggest that around time of delivery, the dose of hydrocortisone should be increased and administered by IV drip in cases of digestive intolerance.

Weak recommendation, level of evidence ++.

ciency is partial or in the case of acute adrenal insufficiency that has just manifested. If acute adrenal insufficiency is suspected, blood samples should be taken and assayed immediately for cortisol and ACTH though treatment should be commenced without waiting for assay results. Treatment should be by parenteral hydrocortisone hemisuccinate, in adults at $100 \mathrm{mg}$ IM or IV then continuous IV infusion at $100 \mathrm{mg} / 24 \mathrm{~h}$ (or via bolus delivered IV or IM at $6 \mathrm{~h}$ intervals). In children, $2 \mathrm{mg} / \mathrm{kg}$ each $6-8 \mathrm{~h}$, IM or SC, or each $6 \mathrm{~h}$ via IV drip, depending on the clinical state. Correction of hypovolemia and hypoglycemia, particularly in children (using G5\% or G10\%), and the loss of electrolytes requires treatment as well as treatment of the cause of adrenal crisis. Clinical improvement after administration of hydrocortisone is the best diagnosis criterion. Ongoing treatment is then by oral administration of hydrocortisone, tripling the usual dose (at least $60 \mathrm{mg} / 24 \mathrm{~h}$ ) splitted in three doses during the course of the day and then gradually reducing the dose over several days to arrive at the normal dose. In adult patients with primary adrenal insufficiency, treatment with fludrocortisone is recommenced when the dose of hydrocortisone is less 
R4-8: in adults, we recommend mineralocorticoid replacement using fludrocortisone at a mean dose of $100 \mu \mathrm{g} /$ day (individually adjusted) and a free intake of dietary sodium in patients with primary adrenal insufficiency with mineralocorticoid deficiency. Patients with corticotroph insufficiency should not be treated with a mineralocorticoid component.

Strong recommendation, level of evidence +++.

In children, we recommend mineralocorticoid replacement using fludrocortisone at a dose of $50-100 \mu \mathrm{g} /$ day. Oral administration of sodium (1-2 g/day) is necessary up to $1-2$ years of age in children with primary adrenal insufficiency with mineralocorticoid deficiency. Children with corticotroph insufficiency should not be treated with mineralocorticoid replacement.

Strong recommendation, level of evidence ++ .

R4-9: in adults, we recommend that monitoring and adjustment of mineralocorticoid replacement be based on clinical and biochemical signs of under-dosage (increased salt appetite, hypotension, nausea, hyponatremia, hyperkalemia, elevated renin) or of overdose (hypertension, edema, hypokalemia, undetectable or lower than normal renin).

Strong recommendation, level of evidence +++.

In children, we recommend monitoring and adjustment of mineralocorticoid replacement based, as in adult patients, on clinical and biochemical signs of under dosage and equally on particular monitoring of growth curves in young children. We recommend maintenance of plasma renin at values from normal to higher than normal levels.

Strong recommendation, level of evidence ++ .

R4-10: we suggest that androgen replacement should be considered in women with primary or secondary adrenal insufficiency who are suffering from an alteration in quality of life, problems with mood and a loss of libido despite optimal glucocorticoid and mineralocorticoid replacement.

Weak recommendation, level of evidence ++

than $50 \mathrm{mg} /$ day. In children, fludrocortisone can be reintroduced when oral hydrocortisone is being administered. Prevention of acute adrenal crisis requires the education of the patient and/or parent, in the case of pediatric patients, and their physician in
R4-11: the initial dose of DHEA for androgen replacement should be $25-50 \mathrm{mg} /$ day over a period of 3 to 6 months, with adjustment of the dose as a function of (i) circulating levels of plasma DHEA during replacement treatment and (ii) the effects on symptoms identified prior to treatment. In the absence of a beneficial effect or in the case of adverse effects of androgen treatment, replacement therapy should be ceased.

Weak recommendation, level of evidence ++.

the following: normal dietary sodium intake, increasing the oral dose of medication in the case of illness, stress or intense activity and the delivery of injectable hydrocortisone hemisuccinate by family/carers or the patient themselves in an emergency as well as carrying a card identifying the patient as suffering from adrenal insufficiency.

\subsubsection{Treatment of acute adrenal crisis}

R5-1: in adults with an adrenal crisis, we recommend injection of hydrocortisone hemisuccinate $100 \mathrm{mg}$ by IM or IV route followed immediately by IV infusion of $100 \mathrm{mg} / 24 \mathrm{~h}$ by syringe pump (alternatively, bolus injection IV or IM of $25 \mathrm{mg}$ each $6 \mathrm{~h})$. Treatment needs to be commenced urgently, after assay for cortisol and ACTH if the diagnosis of adrenal insufficiency was not previously known, and without waiting for results.

After correction of clinical and fluid balance problems, we recommend a return to oral administration of hydrocortisone, tripling the normal dose (at least $60 \mathrm{mg} / 24 \mathrm{~h}$ in patients normally treated with low dose), taken as 3 doses across the day (morning, midday and evening). Return to normal dose should then be by progressive reduction of the dose over several days.

Treatment with fludrocortisone should not be recommenced until the hydrocortisone dose is less than $50 \mathrm{mg} /$ day.

Strong recommendation. Expert opinion.

\subsubsection{Prevention of an adrenal crisis}

2.6. Modalities and frequency of monitoring of patients with adrenal insufficiency. Patient education [6]

Patients with adrenal insufficiency require regular, specialised monitoring in order to optimise their replacement therapy, to detect signs of under- and over-dosage, and to examine for possible associated disorders (auto-immune disorders in the case of auto-immune primary adrenal insufficiency either isolated or as part of auto-immune polyendocrinopathy syn- 
Table 4

Clinical manifestations and recommendations for surveillance of patients with adrenal insufficiency suffering from auto-immune polyendocrinopathy type 1 (PEA1 or APECED syndrome) (additional to specific surveillance of adrenal insufficiency detailed elsewhere).

\begin{tabular}{|c|c|c|c|c|}
\hline Affected organ(s) & $\begin{array}{l}\text { Frequency of } \\
\text { occurrence }\end{array}$ & $\begin{array}{l}\text { Age at } \\
\text { occurrence }\end{array}$ & $\begin{array}{l}\text { Initial tests, then repeated } \\
\text { each } 2-3 \text { years, or sooner } \\
\text { in case of clinical } \\
\text { justification }\end{array}$ & Annual monitoring \\
\hline $\begin{array}{l}\text { Mucocutaneous } \\
\text { manifestations }\end{array}$ & & & $\begin{array}{l}\text { Stomatological } \\
\text { examination } \pm \text { other specialist }\end{array}$ & $\begin{array}{l}\text { Stomatological } \\
\text { examination } \pm \text { other specialist }\end{array}$ \\
\hline $\begin{array}{l}\text { Mucocutaneous candidiasis } \\
\text { Hypoplasia of dental enamel }\end{array}$ & $83-100 \%$ & Childhood & $\begin{array}{l}\text { consultations, dermatology, } \\
\text { opthalmology if necessary }\end{array}$ & $\begin{array}{l}\text { consultations, dermatology, } \\
\text { opthalmology if necessary }\end{array}$ \\
\hline $\begin{array}{l}\text { Alopecia } \\
\text { Keratoconjunctivitis }\end{array}$ & $77 \%$ & Childhood & & \\
\hline Vitiligo & $\begin{array}{l}29-37 \% \\
12-35 \% \\
12-13 \%\end{array}$ & $\begin{array}{l}\text { Childhood } \\
\text { Childhood } \\
\text { Childhood }\end{array}$ & & \\
\hline Endocrine manifestations & & & Review & Review \\
\hline Hypoparathyroidism & $79-93 \%$ & Childhood & Endocrinology screen & Endocrinology screen \\
\hline Ovary (ovaritis) & $60 \%$ & $\begin{array}{l}\text { 2nd to } \\
\text { 3rd decade } \\
\text { 3rd to } \\
\text { 5th decade } \\
\text { 3rd decade }\end{array}$ & $\begin{array}{l}\text { Phosphocalcium levels } \\
\text { FSH, LH } \\
\text { E2 } \\
\text { Or testosterone }\end{array}$ & $\begin{array}{l}\text { Phosphocalcium levels } \\
\text { FSH, LH } \\
\text { E2 } \\
\text { Or testosterone }\end{array}$ \\
\hline Testis & $<25 \%$ & & & \\
\hline Thyroiditis & $3-10 \%$ & & TSH, AC anti-TPO & $\mathrm{TSH}$ \\
\hline Type 1 diabetes & $2-12 \%$ & $\begin{array}{l}\text { 2nd to } \\
\text { 3rd decade }\end{array}$ & $\begin{array}{l}\text { Fasting blood glucose, } \mathrm{AB} \\
\text { anti-IA2, anti-insulin, anti-GAD }\end{array}$ & Fasting blood glucose \\
\hline Lymphocytic hypophysitis & $5-7 \%$ & Childhood & IGF1, FSH, LH, ACTH & IGF1, FSH, LH, ACTH \\
\hline $\begin{array}{l}\text { Gastroenterology } \\
\text { manifestations }\end{array}$ & & & $\begin{array}{l}\text { Examinations } \\
\text { Clinical examination }\end{array}$ & $\begin{array}{l}\text { Examinations, clinical examination } \\
\text { Serum albumin and ferritin }\end{array}$ \\
\hline Malabsorption & $15-18 \%$ & Childhood & $\begin{array}{l}\text { Seum albumin and ferritin } \\
\text { AB anti-GAD65 }\end{array}$ & \\
\hline Hepatitis & $12-20 \%$ & Childhood & $\begin{array}{l}\text { Hepatic function markers } \\
\text { NFS, vitamin B12, anti-intrinsic }\end{array}$ & $\begin{array}{l}\text { Hepatic function markers } \\
\text { NFS, vitamin B12 }\end{array}$ \\
\hline Gastritis & $13-15 \%$ & $\begin{array}{l}\text { 2nd to } \\
\text { 3rd decade }\end{array}$ & $\begin{array}{l}\text { factor and antigastric parietal cell } \\
\text { antibodies }\end{array}$ & \\
\hline $\begin{array}{r}\text { Gastroenterology } \\
\text { manifestations }\end{array}$ & & & $\begin{array}{l}\text { Examinations, } \\
\text { Clinical examination }\end{array}$ & $\begin{array}{l}\text { Examinations, clinical examination } \\
\text { Serum albumin and ferritin }\end{array}$ \\
\hline Malabsorption & $15-18 \%$ & Childhood & Seum albumin and ferritin & Hepatic function markers \\
\hline Hepatitis & $12-20 \%$ & Childhood & AB anti-GAD65 & NFS, vitamin B12 \\
\hline Gastritis & $13-15 \%$ & $\begin{array}{l}\text { 2nd to } \\
\text { 3rd decade }\end{array}$ & $\begin{array}{l}\text { Hepatic function markers } \\
\text { NFS, vitamin B12, anti-intrinsic }\end{array}$ & \\
\hline $\begin{array}{l}\text { Other non-endocrine } \\
\text { manifestations }\end{array}$ & & & $\begin{array}{l}\text { factor and anti-gastric parietal } \\
\text { cell antibodies }\end{array}$ & \\
\hline Interstitial nephritis & $<10 \%$ & $\begin{array}{l}\text { 2nd to } \\
\text { 3rd decade }\end{array}$ & $\begin{array}{l}\text { Urea, creatinine, TA, plasma ions } \\
\text { Clinical examination }+{ }_{-} \text {EFR and }\end{array}$ & $\begin{array}{l}\text { Urea, creatinine, TA, plasma ions } \\
\text { Clinical examination }+{ }_{+} \text {EFR and }\end{array}$ \\
\hline HTA with hypokalemia & $15 \%$ & $\begin{array}{l}\text { Childhood or } \\
\text { young adult }\end{array}$ & $\begin{array}{l}\text { TDM if clinically indicated } \\
\text { NFS, examination for Howell }\end{array}$ & $\begin{array}{l}\text { TDM if clinically indicated } \\
\text { NFS, examination for Howell }\end{array}$ \\
\hline Obliterative bronchiolitis & $10-20 \%$ & & Jolly bodies & Jolly bodies \\
\hline $\begin{array}{l}\text { Splenic atrophy } \\
\text { Auto-immune hemolytic } \\
\text { anemia, large granular } \\
\text { lymphocytic leukemia } \\
\text { Severe infections } \\
\text { Myocarditis } \\
\text { Pulmonary hypertension }\end{array}$ & & & $\begin{array}{l}\text { Abdominal ultrasound } \\
\text { Clinical examination }\end{array}$ & Clinical examination \\
\hline $\begin{array}{l}\text { Progressive muscular atrophy } \\
\text { Vasculitis } \\
\text { Connective tissue disease } \\
\text { Febrile skin rashes } \\
\text { Anxiety, depression }\end{array}$ & & & & \\
\hline
\end{tabular}


R5-2: in adults with an adrenal crisis, we recommend administration of one liter of isotonic saline in the first hour. The speed of infusion and the volume of isotonic saline (with $10 \%$ glucose in cases of hypoglycemia) administered should be modified according to clinical and hemodynamic monitoring of the patient. Treatment should be maintained for 24-48 h. In ACTH insufficiency, treatment should also include isotonic saline IV infusion to correct fluid and electrolyte loss, especially in cases of digestive problems and/or hypotension.

Strong recommendation. Expert opinion.

R5-3: in prepubertal children with an adrenal crisis, we recommend:

- administration of injectable hydrocortisone hemisuccinate (100 $\mathrm{mg}$ ampoule) $2 \mathrm{mg} / \mathrm{kg} / 6 \mathrm{~h}$ in IV drip or each 6-8 h via IM or SC injection;

- parenteral rehydration using $5 \%$ glucose or $10 \%$ glucose in cases of hypoglycemia with provision of $\mathrm{NaCl}$ of $10-15 \mathrm{mEq} / \mathrm{kg} /$ day (maximum $408 \mathrm{mEq} / \mathrm{day}=24 \mathrm{~g}$, plasma sodium must not increase by more than $1 \mathrm{mEq} / \mathrm{kg} / \mathrm{hr}$ ) and provision of fluids according to the age of the patient: newborn: $150-180 \mathrm{~mL} / \mathrm{kg} /$ day; child: 2.5-3 $\mathrm{L} / \mathrm{m}^{2} /$ day. Volume replacement with isotonic saline in case of circulatory collapse $(10-20 \mathrm{~mL} / \mathrm{kg})$ is sometimes necessary;

- clinical monitoring (blood pressure, heart rate, glycemia, urine output, weight, alertness) and biochemical monitoring, adapted for fluid and electrolytes and the speed of their correction, is essential.

Strong recommendation. Expert opinion.

drome type 1, see Table 4; illnesses with underlying monogenic causes). The transition period between adolescence and adulthood represents an added risk of a breakdown in monitoring which requires particular attention from medical teams and coordination between adult and pediatric medical teams.

It is essential to encourage patient autonomy in the management of their illness, notably their participation in treatment education programs, especially programs that target avoidance of, or early treatment of acute adrenal insufficiency. The principal educational objectives for patients in such programs are:
R5-4: in adults we suggest on the day of surgery or intervention, an IM or IV injection of a $100 \mathrm{mg}$ bolus of hydrocortisone hemisuccinate, followed in the case of major surgery, by continuous infusion of hydrocortisone hemisuccinate, $100 \mathrm{mg} / 24 \mathrm{~h}$ (or alternatively $25 \mathrm{mg}$ IM or IV every $6 \mathrm{~h})$, to be continued until patients return to eating. On return to oral treatment, normal dose should be tripled (at least $60 \mathrm{mg} / \mathrm{day}$ ), taken three times per day (morning, midday and evening) before gradual reduction of the dose over a few days to the normal dose. In primary adrenal insufficiency, treatment with fludrocortisone should be recommenced when the hydrocortisone dose has been reduced to $<50 \mathrm{mg} /$ day.

Weak recommendation. Expert opinion.

R5-5: in children, we suggest that on the day of the intervention the same protocol as that used in cases of acute adrenal insufficiency be employed, and continued until the patient returns to eating. When oral treatment is recommenced, the normal dose of hydrocortisone should be tripled and taken in three administrations per day (morning, midday and evening) before progressively reducing the dose over several days to the normal dose. In cases of light anesthesia, minor surgery or examination that requires fasting conditions, we suggest hydrocortisone hemisuccinate $2 \mathrm{mg} / \mathrm{kg} / 4-6 \mathrm{~h}$ by IV injection or each $6-8 \mathrm{~h}$ by IM injection, to be continued if the fasting state continues, and after to return to normal oral hydrocortisone administration.

Weak recommendation. Expert opinion.

- to be able to identify situations of increased risk and the early signs of adrenal crisis;

- to know how to adjust their oral glucocorticoid treatment;

- to be capable of administering hydrocortisone by subcutaneous injection;

- to be able to predict and therefore adjust treatment to different situations (heat, physical exercise, travel);

- to be able to correctly use the appropriate resources of the healthcare services.

Other programs could also be developed to respond to needs and expectations of patients, notably concerning the adjustment of hydrocortisone dosage to avoid overdose in the context of chronic fatigue syndrome. 
R5-6: in childbirth, we suggest the administration to the mother of hydrocortisone hemisuccinate by infusion (syringe pump) $100 \mathrm{mg} / 24 \mathrm{~h}$ (alternatively $25 \mathrm{mg}$ by IM or IV injection each $6 \mathrm{~h}$ ) during the period of labor.

After delivery and in the absence of complications, oral administration can be recommenced using triple the normal dose, taken in three doses across the day before a progressive reduction of the dose and gradual return to normal dosing.

In the case of caesarean section: recommendations are the same as for major surgery. We suggest IM or IV injection of a bolus of $100 \mathrm{mg}$ hydrocortisone hemisuccinate followed by continuous infusion of $100 \mathrm{mg} / 24 \mathrm{~h}$ (or alternatively $25 \mathrm{mg}$ by IM or IV injection every $6 \mathrm{~h}$ ) until the patient returns to oral intake of food. Oral administration of hydrocortisone is then recommenced with triple the normal dose, taken as three doses during the day and then a progressive reduction to return to normal dosing.

Written recommendations for the peri- and post-partum period should be provided to the pregnant patient, obstetricians and anesthetists ensuring that they are followed.

Weak recommendation. Expert opinion.

R5-7: in the adult patient, we suggest that colonoscopy procedures be programmed in the morning. We suggest that a supplementary dose of $20 \mathrm{mg}$ hydrocortisone is taken the evening before and on the morning of the examination, combined with normal oral hydration. Immediately prior to the procedure, an IM or IV injection of $100 \mathrm{mg}$ hydrocortisone hemisuccinate should be administered. From the next day the patient can recommence oral hydrocortisone at the normal dose.

In case of clinical signs suggesting adrenal crisis during the preparation for the examination (intense fatigue, nausea, hypotension) an IM or SC injection of $100 \mathrm{mg}$ hydrocortisone hemisuccinate is recommended.

Strong recommendation. Expert opinion.

\subsection{Perspectives [4]}

The modified release hydrocortisone Duocort (Plenadren ${ }^{\circledR}$ ) has recently been authorized for use in Europe for patients with adrenal insufficiency. This formulation gives a release profile that is more physiological across the day, with two compo-
R5-8: in the adult patient, we recommend, when presenting with acute intercurrent illness, the administration of hydrocortisone hemisuccinate $100 \mathrm{mg} / 24 \mathrm{~h}$ by continuous IV infusion by syringe pump (or alternatively $25 \mathrm{mg}$ by IM or IV injection every $6 \mathrm{~h}$ ).

After correction of the clinical condition and of hemodynamic parameters, we recommend recommencing oral hydrocortisone at triple the normal dose (at least $60 \mathrm{mg} / 24 \mathrm{~h}$ ) administered in three doses per day and with a progressive reduction over several days to return to the normal dose. In patients with primary adrenal insufficiency, treatment with fludrocortisone can be recommenced when the hydrocortisone dose is less than $50 \mathrm{mg} /$ day.

Strong recommendation. Expert opinion.

R5-9: in the pediatric patient, in case of acute intercurrent illness requiring administration of parenteral hydrocortisone hemisuccinate, we recommend a dose of $1-2 \mathrm{mg} / 6 \mathrm{~h}$ by IV drip or each $6-8 \mathrm{~h}$ by IM injection, depending on the clinical state. After correction of the clinical state and hemodynamic parameters, we recommend recommencing oral hydrocortisone treatment with triple the normal dose, taken in 3 administrations per day and with a progressive decrease in dose over several days to return to normal doses. Fludrocortisone can be reintroduced at the same time as oral hydrocortisone is recommenced.

Strong recommendation. Expert opinion.

nents, one that is rapidly released and the other resulting in prolonged release over 12 hours. It does not, however, mimic the peak of cortisol secretion on waking. Duocort treatment during a 6-month period was associated with favourable changes in weight, blood pressure and glycemic control in patients with diabetes mellitus, in comparison with hydrocortisone.

Another modified release hydrocortisone $\left(\right.$ Chronocort $\left.^{\circledR}\right)$ is currently being evaluated for the indication "adrenal enzymatic block". One administration in the evening at $10 \mathrm{pm}$ results in a physiological increase in cortisol during the night. There is therefore the potential for producing, with this drug, a physiological increase in nocturnal concentration of hydrocortisone. The drug is effective in controlling androgen excess in adults with congenital adrenal hyperplasia. Recently, the new multiparticulate formulation Infacort was designed for the treatment of adrenal insufficiency during infancy. These new compounds may help obtaining a physiological glucocorticoid replacement with potential short term and long-term beneficial consequences on 
R5-10: we recommend:

- that all patients are given a card identifying them as requiring urgent medical care, marked "adrenal insufficiency";

- that patients and parents of pediatric patients be educated as to the risks of adrenal insufficiency, how to increase the dose of hydrocortisone themselves in cases of stress, infection, trauma and how to adapt their treatment to altered circumstances (heat, physical exercise, travel);

- patients and their family/carers should be educated in how to perform SC injections of hydrocortisone hemisuccinate;

- all patients should be provided with prescriptions for $100 \mathrm{mg}$ vials of hydrocortisone hemisuccinate, syringes and needles for preparation and delivery of the injection. Patients always need to carry the necessary materials for injection with them;

- there should be regular evaluation of patient knowledge, as well as that of their family/carers and their physician, about their condition.

Strong recommendations. Expert opinion.

R6.1: we recommend that adults with adrenal insufficiency have regular consultation by an endocrinologist at least once per year.

Strong recommendations. Expert opinion.

R6.2: we recommend that children with adrenal insufficiency have regular consultation by a pediatric endocrinologist in a specialised center or reference center two to three times per year and more frequently in babies.

Strong recommendations. Expert opinion.

quality of life, morbidity and mortality in the adrenal insufficient patient.

\section{Disclosure of interest}

F. Castinetti has performed conferences for HAC Pharma, Shire and Viropharma. L. Guignat was a consultant for Viropharma and has performed conferences for HAC Pharma. C. Bouvattier has been occasionally paid for conferences or writing for Sandoz and Ipsen laboratories. Y. Reznik was a consultant for Viropharma, and Shire and has performed conferences for HAC Pharma and Viropharma. O. Chabre has performed confer-
R6-3: in adults, we suggest clinical monitoring based on evidence of signs of over- or under-dosage, particularly for preventing the consequences of chronic overdose in bone, metabolic and cardiovascular parameters. For adjustment of glucocorticoid replacement, we do not recommend routine use of hormonal markers.

In children, we recommend clinical monitoring (growth, puberty) and examination for clinical signs of overdose or under-dosage. We do not recommend routine use of biochemical markers for adjustment of replacement therapy until further validation, except in congenital adrenal hyperplasia where we recommend regular assay of specific biochemical markers. In cases other than congenital adrenal hyperplasia, assay for ACTH is sometimes useful for evaluation of treatment compliance.

In adults and children, for adjustment of mineralocorticoid replacement, we suggest clinical monitoring (blood pressure, salt appetite, lower limb edema) and examination for biochemical signs of under-dosing (hyponatremia, hyperkalemia, elevated renin) or overdosing (hypokalemia, undetectable renin levels or levels in the lower end of normal range).

Weak recommendation. Expert opinion.

R6.4: we recommend that patients with autoimmune primary adrenal insufficiency are examined systematically for associated auto-immune disorders, at least annually and more frequently in cases where there are early clinical signs of such disorders. The range of initial biochemical tests (excluding auto-immune polyendocrinopathy type I) includes: TSH, anti-thyroperoxidase antibodies; fasting blood glucose, anti-GAD antibodies, anti-IA2 (islet antigen 2) antibodies; blood cell count, vitamin B12, anti-gastric parietal cell antibodies, anti-intrinsic factor antibodies and anti-transglutaminase antibodies. The list of tests to be carried out in follow-up includes: $\mathrm{TSH}$, fasted blood glucose, blood cell counts and vitamin B12. Women of child-bearing age should be warned of the risk of premature ovarian insufficiency. First-degree relatives should be warned of the signs of primary adrenal insufficiency and dysthyroidism. We recommend regular screening for

ence for HAC Pharma. All other authors declare that they have no competing interest. 
potential associated pathologies in the case of auto-immune polyendocrinopathy type 1 (Table 1) or in some genetic-linked adrenal insufficiencies.

Strong recommendation. Expert opinion.

R 6.5: we recommend a genetic counselling consultation in patients with adrenal insufficiency where an underlying genetic cause is suspected.

Strong recommendation. Expert opinion.

R 6.6: we recommend the development of patient education programs, particularly programs that aim to avoid or lead to early treatment of acute adrenal insufficiency, for the patients and their family or carers. We recommend the implementation of programs following the HAS (French national health authority) procedure including the stages of education in diagnosis, the application of the program and its evaluation. We recommend the inclusion of the following main educational objectives:

- to always carry the necessary emergency equipment;

- to be able to identify the situations at increased risk and the early symptoms of acute adrenal insufficiency;

- to know how to adjust oral glucocorticoids in acute situations or in anticipation of altered requirements, particularly in situations of: heat, physical exercise, travel, physical or psychological stress;

- to know how to administer hydrocortisone by subcutaneous injection;

- to appropriately use the resources of the healthcare system;

- to be able to explain their pathology and its treatment to a member of their family or carer.

Strong recommendation. Expert opinion.

R6-7: we suggest that the dose of hydrocortisone be adjusted in situations likely to cause acute adrenal insufficiency (see Chapter 5), with in adults, the dose of fludrocortisone being increased by $50 \mu \mathrm{g}$ per $24 \mathrm{~h}$ in the case of extreme heat:

- for adult patients who usually take one $10 \mathrm{mg}$ hydrocortisone tablet in the morning and one at midday, in situations likely to cause acute adrenal insufficiency, we suggest the following advice: "immediately take 2 tablets of hydrocortisone, regardless of the time of day, then 2 tablets in the morning, 2 tablets at midday and 2 tablets in the evening for 2-3 days until symptoms have gone";

- for pediatric patients, we suggest to double or triple the dose of hydrocortisone, splitted into three doses per day, with one dose around midday and one at night. This regimen should be started immediately in the case of a situation of increased risk and continued until $24 \mathrm{~h}$ after symptoms have disappeared. We suggest that situations of prolonged fasting are avoided due to the risk of hypoglycemia.

Weak recommendation. Expert opinion.

R6-8: we suggest that an injection of hydrocortisone be delivered:

- after the second episode of vomiting or diarrhea in less than half a day;

- in the case of altered consciousness where oral administration is not possible;

- during childbirth, general anesthesia or in resuscitation/intensive care.

Weak recommendation. Expert opinion

R6-9: we suggest the following advice for particular circumstances: for intense and prolonged sporting activity in adults and adolescents: "take supplementary $5 \mathrm{mg}$ hydrocortisone every $3 \mathrm{~h}$, commencing $1 \mathrm{~h}$ before the start of physical activity".

In case of air travel greater than $6 \mathrm{hr}$ in adults: "take supplementary $10 \mathrm{mg}$ hydrocortisone every 
$6 \mathrm{~h}$ until breakfast time in the country where you arrive".

In the case of extreme heat and/or excessive sweating: "drink more water than usual and add more salt to food; otherwise in adults, increase fludrocortisone by $50 \mathrm{mg}$ ".

Weak recommendation. Expert opinion

\section{Acknowledgments}

We thank Frederique Albarel, Hervé Lefebvre, Yves Morel, Gerald Raverot and Delphine Vezzosi for their critical reviewing of the manuscript. We thank Ian Darby for translation of the manuscripts.

\section{References}

[1] Chabre, et al. SFE/SFEDP consensus on adrenal insufficiency, part 1: epidemiology of primary and secondary adrenal insufficiency: prevalence and incidence, acute adrenal insufficiency, long-term morbidity and mortality. Ann Endocrinol 2017.

[2] Chanson, et al. SFE/SFEDP consensus on adrenal insufficiency, part 2: screening methods and confirmation of diagnosis. Ann Endocrinol 2017.

[3] Proust Lemoine, et al. SFE/SFEDP consensus on adrenal insufficiency, part 3: strategies for identifying the cause of adrenal insufficiency: diagnostic algorithm. Ann Endocrinol 2017.

[4] Castinetti, et al. SFE/SFEDP consensus on adrenal insufficiency, part 4 replacement therapy for adrenal insufficiency. Ann Endocrinol 2017.

[5] Cortet, et al. SFE/SFEDP consensus on adrenal insufficiency, part 5: acute adrenal insufficiency in adults and pediatric patients. Ann Endocrinol 2017.

[6] Guignat, et al. SFE/SFEDP consensus on adrenal insufficiency, part 6 : modalities and frequency of monitoring of patients with adrenal insufficiency; patient education. Ann Endocrinol 2017. 